\title{
AOR
}

Selected Papers of \#AoIR2019:

The $20^{\text {th }}$ Annual Conference of the

Association of Internet Researchers

Brisbane, Australia / 2-5 October 2019

\section{THE SITUATED HINTERLANDS OF ONLINE GAMING PRACTICES}

\author{
David Cumming \\ Interaction Design Lab, The University of Melbourne \\ Melissa J. Rogerson \\ Interaction Design Lab, The University of Melbourne
}

\section{Introduction}

Previous work has established the existence and research interest of a "digital hinterland" (Rogerson, Gibbs \& Smith, 2017) - online practices surrounding enthusiasts' engagement with a material hobby. This paper extends this notion to consider how online-gaming practices are framed by activities held in material spaces. Through the esports bar spectatorship experience, we describe how attendance substantiates and supports fans' relationship with their fandom. Drawing on literature about esports experiences and hobbyists' practices, we show that shared time and place, attendance, behaviours, and their contribution to an individual's gaming capital (Consalvo, 2007) are important elements of this situated hinterland.

The transformation of professional competitive play into spectacle (Taylor, 2012) is at the core of esports. While characterised as an online activity, large, intricately-staged esports events are produced and spectated in material settings like stadiums (Cumming, 2018) and broadcast online using streaming platforms like Twitch. Spectators contribute to this spectacle (Carter \& Egliston, 2018; van Ditmarsch, 2013): at live stadium events, spectators impart an energy that provides "meanings and social importance to activities" (Taylor, 2012), impacting the spectating experience for both inperson and remote spectators.

\section{Method}

We conducted an ethnography over five months at a Melbourne-based esports bar. We attended the bar for approximately three hours at a time, three times a week, for a total of over 100 hours of observation. We recorded field notes for each session, participated in spectatorship, and held formal and informal conversations with patrons and staff. Linking our observations to the concept of the 'hinterland' highlights the embeddedness Suggested Citation (APA): Cumming, D, Rogerson, M.J. (2019, October 2-5). The Situated Hinterlands of online gaming practices Paper presented at AoIR 2019: The $20^{\text {th }}$ Annual Conference of the Association of Internet Researchers. Brisbane, Australia: AolR. Retrieved from http://spir.aoir.org. 
of online and offline activities in understanding how spectatorship at the bar worked to strengthen the bond between fans and their fandom.

\section{Findings}

Our findings highlight the situated nature of participation in esports spectatorship. Both time and place were important to participants, driving both their attendance at events and the accrual of gaming capital through that attendance.

\section{Time and Place}

The esports spectators in this study were frequently focused on an event, for example, The International 8 (TI8). This landmark Dota 2 tournament was streamed live via Twitch to the bar's many large screens. This real-time streaming was important to participants, allowing them to vicariously experience and participate in the event whilst it happened. Bar patrons had to account for timezone differences between TI8 host city Vancouver and Melbourne, attending the bar from the early hours of the morning into the early afternoon. Despite these inconvenient hours, the bar remained packed throughout the event. The bar provided a focal point for patrons' engagement, whilst the real-time nature of the experience was critical to participation and enjoyment.

\section{Attendance}

This situated connection to time and place drives the value placed on attendance or presence at an event. This leads aficionados to travel to events, frequently at considerable expense and inconvenience. Travel to international events is costly. Even for local events, the effort required to attend can be considerable. Participants invest time in travelling to the event, adjusting work and home timetables to accommodate real-time events, to enjoy an enhanced experience of the event as a member of a group.

This aligns with broader practices of sports (Kurtzman \& Zauhar, 2005; Weed \& Bull, 2009) and media tourism (Connell, 2012; Parmett, 2016) and evokes practices of other serious leisure groups. Lax and Mackenzie (2019) discuss a 'gacha' gamer ${ }^{1}$ who travelled from Japan to the UK to attempt to obtain a premium King Arthur character by purchasing in-game gacha at the legendary King's purported grave ${ }^{2}$, and Rogerson, Gibbs and Smith (2019) describe boardgamers' valorization of key hobbyist events. Sports fans share this strong identification with places, for example Lord's cricket ground in London, which is seen as the "home of cricket" (Cardwell \& Alli 2014), and fans of media franchises visit key filming locations and places mentioned in texts (Jewell \& McKinnon, 2008; Tzanelli \& Yar, 2016).

\section{Shared behaviours}

For enthusiasts who cannot or choose not to attend an event, local alternatives offer another possibility for attendance. Although these events lack the prestige and authenticity of the main event (Cardwell \& Alli, 2014; Lamont, 2014), they nevertheless provide an attendance experience beyond the mundane (Weed, 2007). Participants' experience of $T / 8$ was not inherent to the bar itself. Rather, spectators produced their own experience based on their expectations of what such an experience would entail, drawing on behaviours performed by the crowd depicted on the live-stream. Through the engagement of spectating rituals and replication of observed behaviours, they were 
reterritorialised by spectators in the bar (Deleuze \& Guattari, 1988). Rather than exactly replicating the stadium experience, they appropriated and produced key characteristics of it in their own local context, creating a distinct yet, from the patrons' perspective, authentic experience.

\section{Gaming Capital}

This shared, partisan experience offers intrinsic benefits of enhanced enjoyment as well as a feeling of belonging and exclusivity (Weed, 2006). Urry (2002) describes the act of "collecting places". The gathering of artifacts and stories from event attendance can be used to retell experiences and demonstrate strong commitment to a hobby. Throughout the night, spectators of $T / 8$ reminisced about watching other esports events at the bar as social boundaries dissolved. By the end of the event it was clear that the shared communal experience of watching $T / 8$ at the bar would become a part of the patrons' accrued gaming capital; several groups discussed how they would boast to their nonattending friends about "missing out".

\section{Conclusion}

This paper describes how attendance at an esports bar demonstrates commitment to the esports fandom. While fans engage in spectatorship in the bar, it is the elements surrounding the spectatorship which attract gaming capital. With the bar offering a local alternative for spectatorship, travel to and attendance at the bar offers a sense of exclusivity and camaraderie. Patrons partook in a shared experience, which could later be retold to others to demonstrate commitment to the fandom. Whereas Rogerson, Gibbs and Smith (2017) demonstrate that a digital hinterland of online practices frames material boardgaming experiences, this paper shows that a situated hinterland encompassing time and place surrounds and extends the online practices of esports spectatorship. Such findings demonstrate that hobbies should not be characterised as solely online or material; they are informed by engagement beyond their origin.

\section{References}

Cardwell, D., \& Nazia, A. (2014). Nostalgia at the Boundary: A Study at Lord's Cricket Ground. In T. Baum, \& B. Richard (Eds.), Tourism and Cricket: Travels to the Boundary. Channel View Publications.

Carter, M., \& Egliston, B. (2018). Audiencing on Twitch. In Abstract Proceedings of the 2018 DiGRA International Conference, Turin, Italy

Connell, J. (2012). Film tourism-Evolution, progress and prospects. Tourism management, 33(5), 1007-1029.

Consalvo, M. (2007). Cheating : Gaining Advantage in Videogames. Cambridge, MA: MIT Press.

Cumming, D. (2018). Understanding the experience of Australian eSports spectatorship. DiGRA 2018 - Proceedings of The 11th Digital Games Research Association Conference, Turin, Italy. 
Deleuze, G., \& Guattari, F. (1988). A thousand plateaus: Capitalism and schizophrenia. Bloomsbury Publishing.

Jewell, B., \& McKinnon, S. (2008). Movie tourism-A new form of cultural landscape? Journal of Travel \& Tourism Marketing, 24(2-3), 153-162.

Kurtzman, J., \& Zauhar, J. (2005). Sports tourism consumer motivation. Journal of Sport Tourism, 10(1), 21-31.

Lamont, M. (2014). Authentication in sports tourism. Annals of Tourism Research, 45, 117.

Lax, G.L., \& Mackenzie, M. (2019). Against All Odds: Desire and Monetisation in Japanese Mobile Games. DiGRAA 2019: What's Next?, Sydney, Australia.

Parmett, H.M. (2016). It's HBO: Passionate engagement, TV branding, and tourism in the postbroadcast Era. Communication and Critical/Cultural Studies, 13(1), 3-22.

Rogerson, M.J., Gibbs, M., \& Smith, W. (2017). Exploring the Digital Hinterland. AOIR 2017, Tartu, Estonia.

Rogerson, M.J., Gibbs, M., \& Smith, W. (2019). Understanding the travel motivations of game hobbyists. DiGRAA 2019: What's Next?, Sydney, Australia.

Taylor, T.L. (2012). Raising the Stakes: E-sports and the Professionalization of Computer Gaming. Mit Press.

Tzanelli, R., \& Yar, M. (2016). Breaking Bad, making good: Notes on a televisual tourist industry. Mobilities, 11(2), 188-206.

Urry, J. (2002). The Tourist Gaze. London: Sage.

van Ditmarsch, J.L. (2013). Video games as a spectator sport. (Master's thesis). Utrecht: Utrecht University.

Weed, M. (2006). The story of an ethnography: The experience of watching the 2002 World Cup in the pub. Soccer \& Society, 7(1), 76-95.

Weed, M. (2007). The pub as a virtual football fandom venue: An alternative to 'being there'?. Soccer \& Society, 8(2-3), 399-414.

Weed, M., \& Bull, C. (2009). Sports tourism: Participants, policy and providers (2nd ed.). Oxford: Butterworth-Heinemann. 
1 'Gacha' games, popular in Japan, are digital games which offer a monetised mechanic based on the 'gacha' machines where players attempt to win a capsule toy. Analogous to loot boxes, gacha provide characters and other items that assist players and may be required for progression.

2 https://twitter.com/hinata5DX/status/1035921881839411201 